\title{
KONTRIBUSI KEPEMIMPINAN KEPALA MADRASAH DAN KINERJA GURU TERHADAP HASIL BELAJAR SISWA DI MAN SUMPUR BATIPUH SELATAN KABUPATEN TANAH DATAR
}

\author{
Irawati Fauziah \\ Guru MAN Sumpur, Koresponden:J alan Simpang Payo Sumpur \\ Kecamatan Batipuh Selatan Kabupaten Tanah Datar.
}

$1300 k$

\begin{abstract}
Contribution Leadershipof Headmaster and Teacher Performance Toward Students' Achievement MAN Sumpur Batipuh Selatan Tanah Datar. This study aims toreveal how much the contribution of leadership headmaster and teacher performance to student learning outcomes in Madrasah Aliyah Negeri (MAN/Islamic Senior High School) Sumpur Batipuh Selatan. The hypothesis ofthis study were: (1) Leadership Principals contribute significantly to the performance of the teacher in Madrasah Aliyah Negeri (MAN/Islamic Senior High School) Sumpur Batipuh Selatan Tanah Datar, (2) teacher performance contributes significantly to student learning outcomes in Madrasah Aliyah Negeri (MAN/Senior Islamic High School) Sumpur Tanah Datar, (3) Leadership Principal sand teacher performance are equally contribute significantly to students' learning outcomes in the country Madrasah Aliyah Negeri (MAN/Islamic Senior High School) Sumpur Batipuh Selatan Tanah Datar.

The results showedthat: (1) The leadership of headmaster is significantly by $38,1 \%$ (Thirty eight poin one percent) of the student learning outcomes in Madrasah Aliyah Negeri (MAN/Islamic Senior High School) Sumpur Batipuh Selatan, (2) the performance of teachers contribute 64,8\% (Sixty four poin eight percent) of the student learning outcomes in Madrasah Aliyah Negeri (MAN/Islamic Senior High School) Sumpur BatipuhSelatan, (3) leadership of headmaster and teacher performance together contribute significantly by $58,8 \%$ (Fifty eight poin eight percent) of the student learning outcomes in the country Madrasah Aliyah Negeri (MAN/Islamic SeniorHigh School) Sumpur Batipuh Selatan Tanah Datar.

The leadership of headmaster and teacher performance are two important factors that cancontribute toward students' learning outcomes in the Madrasah Aliyah Negeri (MAN/Islamic Senior High School) Sumpur Batipuh Selatan Tanah Datar.
\end{abstract}

Kata Kunci: Kepemimpinan kepala madasah, kinerja guru, hasil belajar siswa

\section{PENDAHULUAN}

Kepemimpinan merupakan salah satu faktor yang menentukan kesuksesan manajemen madrasah.Kepemimpinan adalah kemampuan yang dimiliki oleh seseorang untuk mempengaruhi orang lain. Hal ini mengandung makna bahwa kepemimpinan merupakan suatu kemampuan seseorang 
untuk mempengaruhi orang lain tunduk atau mengikuti semua keinginan seorang pemimpin (Jerry, 2012:6).

Kontribusi kepemimpinan dalam kaitannya dengan upaya peningkatan mutu pendidikan, dimana para kepala madrasah mampu mempengaruhi dan memotivasi para guru dan warga madrasah. Hal ini mendukung kenapa figur seorang pemimpin diperlukan, hal ini dikarenakan: 1) banyak orang memerlukan figur pemimpin, 2) dalam beberapa situasi seorang pemimpin perlu tampil mewakili kelompoknya, 3) sebagai tempat pengambil alih resiko bila terjadi tekanan terhadap kelompoknya, dan 4) sebagai tempat untuk meletakkan kekuasaan (Nurkolis, 2003:152). Peranan kepemimpinan kepala madrasah dalam lingkungan madrasah memberikan pengaruh positif terhadap perkembangan guru dalam segala aspek. Bersamaan dengan perkembangan kemampuan guru tersebut dapat menunjang keberhasilan hasil belajar siswa.

Dalam proses pencapaian hasil belajar sangat dipengaruhi oleh berbagai faktor. Salah satu faktor utama yang sangat berpengaruh dalam keberhasilan pembelajaran adalah keberadaan guru. Tugas guru yang utama berdasarkan profesinya adalah mendidik, mengajar dan melatih. Mendidik berarti meneruskan mengembangkan nilai-nilai hidup, sementara mengajar meneruskan dan mengembangkan ilmu pengetahuan dan teknologi. Akhirnya melatih berarti mengembangkan keterampilan-keterampilan kepada para siswa (Moh. Uzer, 2002:45). Mengingat keberadaan guru dalam proses kegiatan belajar mengajar sangat berpengaruh, maka sudah semestinya kualitas guru harus diperhatikan.

Hasil belajar merupakan hasil yang dicapai setelah melalui proses kegiatan belajar mengajar. Hasil belajar merupakan peroses dalam diri individu yang berinteraksi dengan lingkungan untuk mendapatkan perubahan dalam prilakunya (Purwanto, 2009:39).Hasil belajar dapat ditunjukkan melalui nilai yang diberikan oleh seorang guru dari jumlah bidang studi yang telah dipelajari oleh peserta didik. Setiap kegiatan pembelajaran tentunya selalu mengharapkan akan menghasilkan pembelajaran yang maksimal.

Berikut merupakan gambaran hasil belajar siswa dari nilai Ujian Nasional Tahun Pelajaran 2012/2013 dan 2013/2014:

Tabel 1.

Daftar Nilai UN MAN Sumpur TP 2012/2013

\begin{tabular}{|c|c|c|c|c|}
\hline \multirow{2}{*}{ No } & \multirow{2}{*}{ Mata Pelajaran } & \multicolumn{3}{|c|}{ Nilai Rata-Rata } \\
\hline & & IPA & IPS & AGAMA \\
\hline 1 & Bahasa Indonesia & 7,31 & 6,84 & 6,75 \\
\hline 2 & Bahasa Inggris & 6,62 & 6,61 & 4,70 \\
\hline 3 & Matematika & 5,44 & 5,75 & 5,42 \\
\hline 4 & Biologi & 6,33 & & \\
\hline 5 & Kimia & 6,67 & & \\
\hline 6 & Fisika & 4,92 & & \\
\hline 7 & Ekonomi & & 5,73 & \\
\hline 8 & Sosiologi & & 6,66 & \\
\hline 9 & Geografi & & 5,68 & \\
\hline 10 & Hadis & & & 6,67 \\
\hline 11 & Fiqih & & & 6,80 \\
\hline 12 & Tafsir & & & 6,53 \\
\hline
\end{tabular}

Sumber data: Kantor Kementrian Pendidikan dan Kebudayaan Kabupaten Tanah Datar TP 2012/2013

Tabel 2

Daftar Nilai UN MAN Sumpur TP 2013/2014

\begin{tabular}{|c|l|l|l|l|}
\hline \multirow{2}{*}{ No } & \multirow{2}{*}{ Mata Pelajaran } & \multicolumn{3}{|c|}{ Nilai Rata-Rata } \\
\cline { 3 - 5 } & & \multicolumn{1}{|c|}{ IPA } & \multicolumn{1}{c|}{ IPS } & AGAMA \\
\hline 1 & Bahasa Indonesia & 7.61 & 7.08 & 7.18 \\
\hline 2 & Bahasa Inggris & 4.57 & 4.08 & 4.00 \\
\hline 3 & Matematika & 3.90 & 4.57 & 4.65 \\
\hline
\end{tabular}




\begin{tabular}{|c|l|l|l|l|}
\hline 4 & Biologi & 5.69 & & \\
\hline 5 & Kimia & 3.94 & & \\
\hline 6 & Fisika & 4.25 & & \\
\hline 7 & Ekonomi & & 5.09 & \\
\hline 8 & Sosiologi & & 6.50 & \\
\hline 9 & Geografi & & 5.98 & \\
\hline 10 & Hadis & & & 7.72 \\
\hline 11 & Fiqih & & & 6.02 \\
\hline 12 & Tafsir & & & 7.23 \\
\hline
\end{tabular}

Sumber data: Kantor Kementrian Pendidikan dan Kebudayaan KabupatenTanah Datar TP 2013/2014

Atas dasar wacana yang ada di lapangan, terlihat bahwa hsil belajar siswaMAN Sumpur pada tahun ajaran 2013/2014 menurun dibandingkan dengan hasil belajar siswa tahhun ajaran 2012/2013. Maka penulis ingin membuktikan apakah persepsi yang ada di kalangan masyarakat mengenai masalah kontribusi kepemimpinan kepala sekolah dan profesionalisme guru itu benar atau sebaliknya, dengan melakukan suatu penelitian.

Dalam mendapatkan data dari hasil penelitian ini, yang akan dijadikan subyek penelitian adalah populasi tenaga pengajar yang terdiri dari 40 orang yang ada di MAN Sumpur kecamatan Batipuh Selatan. Seperti yang dijelaskan oleh Sudjana dalam Abdul Halim Hanafi bahwa populasi adalah totalitas semua nilai yang mungkin hasil menghitung atau mengukur secara kuantitatif maupun kualitatif dari suatu realitas yang mempunyai karakteristik tertentu dan jelas yang ingin dipelajari sifat-sifatnya (Abdul Halim Hanafi, 2010:78)

Untuk memudahkan penelitian ini, maka perlu diambil sebahagian saja dari jumlah populasi yang biasa disebut dengan sampel.Sampel adalah sebagian dari jumlah dan karekteristik yang dimilki oleh populasi(Sugiyono, 2006:7). Maka, berdasarkan hasil anlisis, sampel dari penelitian ini sebanyak 35 orang tenaga pengajar di MAN Sumpur kecamatan Batipuh Selatan Kabupaten Tanah Datar.

Dalam penelitian ini, pengumpulan data dilakukan dengan menggunakan kuesioner. Kuesioner merupakan butir-butir pertanyaan dan data yang diperoleh dari hasil jawaban responden terhadap pertanyaan yang diajukan dengan menggunakan skala Likert untuk mendapatkan data masing-masing variabel (Sugiyono, 2006:93). Kuesioner ini digunakan untuk mengumpulkan data ketiga variabel yaitu variabel kontribusi kepemimpinan kepala madrasah (X1), kinerja guru (X2) dan hasil belajar siswa $(\mathrm{Y})$.

Pengumpulan data dilakukan dengan menggunakan angket skala Likert sebagai instrumennya. Instrumen ini dipandang cocok untuk mengukur sikap, pendapat dan persepsi sesorang terhadap objek-objek tertentu. Menurut Suharsimi Arikunto, Skala Likert berisi lima alternatif jawaban, yaitu: selalu (SL), sering (SR), kadang-kadang (KD), jarang (JR), tidak pernah (TP). Jawaban untuk pernyataan positif diberi nilai SL skornya 5, SR skornya 4, KD skornya 3, JR skornya 2 dan TP skornya 1 . Untuk pernyataan negative nilainya SL skornya 1, SR skornya $2, \mathrm{KD}$ skornya 3, JR skornya 4 dan TP skornya 5 (Suharsimi Arikunto, 2010:190).

Instrumen yang sudah disusun diujicobakan terlebih dahulu supaya mendapat instrument yang valid dan reliabel. Instrumen inilah yang digunakan untuk penelitian dan diharapkan akan tinggi tingkat kepercayaannya. Prosedur pelaksanaan uji 
coba adalah sebagai berikut: 1) menentukan responden untuk uji coba, 2) melaksanakan uji coba, 3) menganalisis uji coba untuk melihat valid dan reliabelnya instrument. Setelah diisi oleh respondent maka instrument dikumpulkan untuk dianalisis dengan menggunakan teknik analisis SPSS versi 16.0

Tujuan dari penelitian ini adalah untuk mengetahui apakah terdapat pengaruh yang signifikan antara kepemimpinan kepala madrasah dan kinerja guru terhadap hasil belajar siswa Madrasah Aliyah Negeri (MAN) Sumpur kecamatan Batipuh Selatan Kabupaten Tanah Datar.

Penelitian ini diharapkan berguna bagi kepala Madrasah, khususnya kepala Madrasah Aliyah Negeri (MAN) Sumpur kecamatan Batipuh Selatan sebagai bahan masukan untuk pembinaan kinerja guru. Bagi guru, khususnya guru Madrasah Aliyah Negeri (MAN) Sumpur kecamatan Batipuh Selatan, hasil penenlitian ini dapat bermanfaat untuk mengetahui kinerjanya pada masa lalu sehingga bisa menjadi feed back dan perbaikan pada masa mendatang.

\section{PEMBAHASAN}

\section{Deskripsi Variabel Penelitian}

Deskripsi data dari hasil penelitian dimaksudkan untuk memberikan gambaran umum mengenai penyebaran atau distribusi data, aik yang berupa ukuran gejala sentral, ukuran letak maupun distribusi frekuensi. Data yang akan disajikan setelah diolah dari data mentah akan dianalisis menggunakan software versi 16.0.
Deskripsi data dikelompokkan menjadi tiga bagian yaitu, Kepemimpinan Kepala Sekolah $\left(\mathrm{X}_{1}\right)$, Kinerja Guru $\left(\mathrm{X}_{2}\right)$, dan Hasil Belajar Siswa $(\mathrm{Y})$.

\section{a. Variabel Kepemimpinan Kepala Madrasah}

Distribusi skor untuk variabel kontribusi kepemimpinan kepala madrasah yang diperoleh dari 44 butir pernyataan menyebar antara skor terendah 111 sampai skor tertinggi 206. Sedangkan skor minimal 44 dan maksimal yang mungkin terjadi adalah 220 dan Perhitungan distribusi skor tersebut menghasilkan ratarata (mean) sebesar 169,34 simpangan baku (deviation standard) sebesar 23,986 dan median sebesar 180 skor rata-rata dan skor median tidak jauh berbeda. Hal ini merupakan salah satu indikasi bahwa skor variabel kontribusi kepala madrasah cendrung membentuk distribusi normal.

b. Variabel Kinerja Guru

Distribusi skor variabel partisipasi masyarakat sebanyak 44 butir peryataan menyebar dari skor terendah yaitu 148 sampai skor tertinggi 218. Sedangkan skor minimal dan maksimal yang mungkin terjadi adalah 44 dan 220. Perhitungan distribusi skor tersebut menghasilkan ratarata (mean) sebesar 186,94 simpangan baku (deviation standard) sebesar 19,014 dan median sebesar 187,00 . Skor rata-rata dan skor median tidak jauh berbeda. Hal ini merupakan salah satu indikasi bahwa skor variabel kinerja gru cendrung membentuk distribusi normal. 


\section{c. Variabel Hasil Belajar Siswa}

Berdasarkan data yang terjaring dari 35 butir peryataan instrument, distribusi skor untuk pernyataan hasil belajar siswa menyebar antara skor terendah 86 sampai skor tertinggi 138 . Sedangkan skor minimal dan maksimal yang mungkin terjadi adalah 28 dan 140 Perhitungan distribusi skor tersebut menghasilkan ratarata (mean) sebesar 107,97 simpangan baku (deviation standard) sebesar 11,681 dan median sebesar 105,00 Skor rata-rata dan skor median tidak jauh berbeda. Hal ini merupakan salah satu indikasi bahwa skor variabel hasil belajar siswa cendrung membentuk distribusi normal.

\section{Uji Hipotesis}

Masalah penelitian akan dijawab dengan tiga hipotesis, yaitu:

\begin{tabular}{|l|l|}
\hline Hipotesis 1 & $\begin{array}{l}\text { Kontribusi kepemimpinan kepala madrasah } \\
\text { berpengaruh terhadap hasil belajar siswa. }\end{array}$ \\
\hline Hipotesis 2 & $\begin{array}{l}\text { Kinerja guru berpengaruh terhadap hasil belajar } \\
\text { siswa. }\end{array}$ \\
\hline Hipotesis 3 & $\begin{array}{l}\text { Kontribusi kepemimpinan kepala madrasah dan } \\
\text { kinerja guru secara bersama-sama berpengaruh } \\
\text { terhadap hasil belajar siswa. }\end{array}$ \\
\hline
\end{tabular}

Untuk menguji hipotesis pertama yaitu kontribusi kepemimpinan kepala madrasah (X1) berpengaruh terhadap hasil belajar siswa (Y) dapat dilakukan dengan teknik analisis korelasi dan regresi sederhana analisis menghasilkan angka koevisien korelasi dan koevisien determinasi X1 dan Y. Untuk memeriksa apakah pengaruh X1 bersifat prediktif atau tidak dilakukan regresi sederhana. Kemudian diperiksa keberartian pengaruh dan kelinieritasannya dengan menggunakan uji $\mathrm{F}$. Tingkat signifikansi yang digunakan $\alpha=5 \%$
/ 0,05, kriteria pengujian $\mathrm{H}_{0}$ diterima jika $\mathrm{t}$ hitung < tabel dan H0 ditolak jika t hitung $>\mathrm{t}$ tabel.

Selanjutnya untuk menguji hipotesis kedua yaitu kinerja guru (X2) berpengaruh terhadap hasil belajar siswa $(\mathrm{Y})$ dapat dilakukan dengan teknik analisis korelasi dan regresi sederhana analisis menghasilkan angka koevisien korelasi dan koevisien determinasi X2 dan Y. Untuk memeriksa apakah pengaruh X2 bersifat prediktif atau tidak dilakukan regresi sederhana. Kemudian diperiksa keberartian pengaruh dan kelinieritasannya dengan menggunakan uji $\mathrm{F}$. Tingkat signifikansi yang digunakan $\alpha=5 \%$ / 0,05, kriteria pengujian H0 diterima jika $\mathrm{t}$ hitung $<\mathrm{t}$ tabel dan $\mathrm{H} 0$ ditolak jika $\mathrm{t}$ hitung $>\mathrm{t}$ tabel.

Yang ketiga atau hipotesis yang terakhir, yaitu kontribusi kepemimpinan kepala madrasah (X1) dan kinerja guru (X2) secara bersama-sama berpengaruh terhadap hasil belajar siswa( $(\mathrm{Y})$, diuji dengan menggunakan teknik analisis korelasi dan regresi ganda. Pengujian ini dilakukan dengan menghitung persamaan regresi ganda dan diperiksa keberartian serta kelinierannya dengan menggunakan uji F. Kemudian diperiksa korelasi kedua variable bebas secara bersamasama dengan variable terikat sehingga diperoleh koefisien korelasi dan koefisien determinasi. Tingkat signifikansi yang digunakan $\alpha=5 \%$ / 0,05 . Kriteria pengujian adalah. $\mathrm{H}_{0}$ diterima bila F hitung $<\mathrm{F}$ tabel dan $\mathrm{H}_{0}$ ditolak bila $\mathrm{F}$ hitung $>$ F tabel.

\section{Temuan Penelitian}

Berdasarkan pada hasil analisis data dan tingkat pencapaian respon guru Madrasah Aliyah Negri (MAN) Sumpur Batipuh Selatan 
Kabupaten Tanah Datar terhadap variabelvariabel yang diteliti maka dapat diperjelas bahwa kontribusi kepemimpinan kepala madrasah terhadap variabel hasil belajar siswa temasuk kategori baik $(38,1 \%)$, untuk variabel kinerja guru terhadap hasil belajar siswa termsuk kategori baik (64,8\%), sedangkan kontribusi kepemimpinan kepala madrasah dan kinerja guru sama-sama berpengaruh terhadap hasil belajar siswa termasuk kategori sedang $(58,8 \%)$, dan perlu ditingkatkan. Temuan penelitian ini berbeda dengan hasil pengamatan awal yang peneliti lakukan. Pengamatan awal menemukan bahwa kinerja guru Madrasah Aliyah Negri (MAN) di Batipuh Selatan Kabupaten Tanah Datar terlihat masih rendah. Perbedaan temuan penelitian dengan temuan pengamatan awal terjadi karena hasil pengukuran yang dilakukan berdasarkan pengamatan saja atau tanpa instrumen yang valid dan reliabel tidak cukup kuat untuk dijadikan dasar dalam melakukan generalisasi, sehingga perlu dilakukan penelitian yang sistematis sesuai dengan prosedur untuk mendapatkan pembuktian dan kebenaran secara empiris.

Hasil analisis data dan pengujian hipotesis menunjukan bahwa ketiga hipotesis yang diuji dalam penelitian ini dapat diterima. Hasil analisis data menunjukkan bahwa kepemimpinan kepala madrasah dan kerja guru baik secara sendiri-sendiri atau bersamabersama memiliki pengaruh atau peranan yang berarti untuk meningkatkan kinerja guru Madrasah Aliyah Negri (MAN) Batipuh Selatan Kabupaten Tanah Datar.

Dari hasil analisis yang telah dikemukakan pada bagian sebelumnya dapat dijelaskan bahwa masing-masing variabel bebas berkorelasi secara signifikan dan positif dengan variabel terikat. Hasil analisis data dan pengujian hipotesis menunjukan bahwa ketiga hipoteisi yang diuji dalam penelitian yang diterima secara empiris. Dengan demikian, dapat diyakini bahwa variabel Kontribusi Kepemimpinan Kepala Madrasah Aliyah Negri (MAN) Sumpur Batipuh Selatan Kabupaten Tanah Datar dan juga kinerja guru juga pengaruh tergadap variabel hasil belajar siswa. Namun bila keberadaan konstribusi kepemimpinan kepala madrsah terhadap hasil belajarsiswa pada Madrasah Aliyah Negeri (MAN) Sumpur Kabupaten Tanah Datar, maka variabel Kontribusi Kepemimpinan Kepala Madrasah memberikan pengaruh yang lebih besar terhadap variabel hasil belajar siswa pada Madrasah Aliyah Negri (MAN) Kabupaten Tanah Datar sebesar 38,1\% dibandingkan dengan variabel Kinerja guru sebesar 64,8\%.

Melihat hasil perolehan pencapain responden terhadap variabel kontribusi kepemimpinan kepala madrsah baik secara keseluruhan maupun per-indikator menunjukkan kontribusi kepemimpinan kepala madrasah yang terjadi pada MAN Sumpur Kecamatan batipuh Selatan Kabupaten Tanah Datar sudah berjalan dengan baik.

Kontribusi dalam sebuah organisasi memiliki peranan yang penting, kontribusi adalah sebagai suatu sumbangan dari satu pihak kepihak lain. Dalam suatu madrasah kontribusi dapat terjadi secara pertikal antara kepala madrasah dengan guru-guru dan pegawai atau secara horizontal sesama guru dengan guru. 
Kontribusi yang lancar dalam suatu madrasah akan memberikan manfaat yang banyak terhadap perkembangan madrasah juga sangat berpengaruh terhadap hasil belajar siswa. Secara lebih jelas, apabila kontribusi kepemimpina kepala madrasah berjalandengan baik maka madrasah tesebut akan lebih cepat maju dan berkembang dengan baik.

Suatu madrasah yang selalu melakukan kontribusi yang baik dan lancar, maka untuk meningkatkan hasil belajar siswa. Kontribusi kepemimpinan kepala madrasah sebagai penanggung jawab terhadap keberhasilan suatu madrasah dan hasil belajar siswa dan juga mengembangkan pola kontribusi yang baik.

\section{PENUTUP}

\section{Kesimpulan}

Berdasarkan hasil penelitian dan pembahasan yang telah dikemukakan di atas dapat ditarik kesimpulan sebagai berikut:

a. Kontribusi Kepemimpinan Kepala MAN Sumpur Kecamatan Batipuh Selatan berpengaruh signifikan sebesar 0,381\% terhadap hasil belajar siswa MAN Sumpur Kecamatan Batipuh Selatan Kabupaten Tanah Datar. Ini berarti bahwa apabila konntribusi kepala madrasah baik dan lancar maka hasil belajar siswa cendrung akan meningkat, begitu pula sebalikya.

b. Kinerja guru berkontribusi secara signifikan sebesar 0,648 \% terhadap hasil belajar siswa MAN Sumpur Kecamatan Batipuh Selatan. Ini berarti bahwa apabila kinerja guru rendah maka hasil belajar siswa cendrung akan menurun, begitu pula sebalikya.

c. Kontribusi kepemimpinan kepala madrasah dan kinerja guru secara bersama-sama berpengaruh signifikan sebesar 58,8\% terhadap hasil belajar siswa. Ini berarti bahwa apabila kontribusi kepemimpinan kepala madrasah dan kinerja guru baik dan tinggi maka hasil belajar anak cendrung akan meningkat, begitu pula sebalikya. Hal ini merupakan gambaran terhadap kontribusi kepemimpinan kepala madrasah, kinerja guru,dan hasil belajar siswa MAN Sumpur Kecamatan Batipuh Selatan Kabupaten Tanah Datar.

Dari hasil analisis ketiga hipotesis yang diajukan telah teruji secara impiris. Hasil uji hipotesis ini menunjukan bahwa kontribusi kepemimpinan kepala madrasah dan kinerja guru memberikan pengaruh yang signifikan terhadap hasil belajar siswa baik secara sendirisendiri mapun bersama-sama. Hal ini berarti untuk meningkatkan hasil belajar siswa MAN Sumpur Batipuh Selatan Kabupaten Tanah Datar dapat melalui memperbaiki kontribusi kepemimpinan dan meningkatkan kinerja guru.

Berdasarkan hasil penelitian dari skor jawaban responden yang telah dianalisis dan dikelompokkan, memperlihatkan bahwa klasifikasi rata-rata untuk variabel hasil belajar berada dalam kategori sedang, variabel kontribusi kepemimpinan kepala madrasah berada dalam kategori baik, dan adapun variabel kinerja guru berada dalam kategori sedang. 
Temuan ini membawa implikasi terhadap pentingnya kepala madrasah meningkatkan kontribusi dan peran serta kinerja guru terhadap hasil belajar siswa pada umumnya. Madrasah yang berada dibawah pimpinan kepala madrasah khusunya yang merupakan dua prediktor terhadap tinggi rendahnya hasil belajar yang di dapat di madrasah. Hal ini berarti kontribusi kepemimpinan kepala madrasah perlu bekerja keras untuk terus meningkatkan kontribusinya dan peran serta kinerja guru agar hasil belajar siswa MAN Sumpur Kecamatan Batipuh Selatan Kabupaten Tanah Datar dapat meningkat dan berkembang di era pendidikan pada masa sekarang.

\section{Saran}

Berdasarkan hasil penelitian dan implikasi yang telah dikemukakan, maka peneliti mengemukakan saran sebagai rekomendasi kepada berbagai pihak sebagai berikut: Kepala Sekolah dan Tenaga Pengajar di MAN Sumpur:

a. Kepada kepala MAN Sumpur Kecamatan Batipuh Selatan Kabupaten Tanah Datar untuk dapat menyadari pentingnya peranan kontribusi dan kinerja guru dalam menigkatkan hasil belajar siswa, karena dengan adanya kontribusi yang efektif dapat meningkatkan kemampuan manajerial kepala madrasah dengan berkontribusi sosial sesama bawahan, dengan manajerial dan kontribusi sosial yang baik akan dapat menggerakkan bawahan untuk mencapai tujuan dalam suatu madrasah, yaitu meningkatkan hasil belajar siswa. Kepala madrasah juga diharapkan sering berkerja sama dengan komite madrasah sebagai perpanjangan tangan dari masyarakat luas, melibatkan masyarakat dalam kegiatan-kegiatan yang dilaksanakan oleh madrasah serta melibatkan masyarakat dalam mengambil keputusan.

b. Kepada pemerintah yang tekait lansung dengan dunia pendidikan untuk selalu memberikan arahan tentang kontribusi kepemimpinan kepala madrasah kepada kepala-kepala madrasah dan juga mensosialisasikan kepada masyarakat bahwa tanggung jawab pendidikan dan hasil belajar siswa tidak hanya tanggung jawab kepemimpinan dan guru semata akan tetapi juga tanggung jawab masyarakat.

c. Bagi peneliti lain yang tertarik untuk melakukan pengkajian lebih mendalam tentang hasil belajar siswa agar lebih memperluas bahasan tentang faktor-faktor lain yang diduga dapat mempengaruhi hasil belajar.

d. Progran Studi Manajemen Pendidikan Islam STAIN Batusangkar, sebagai bahan tambahan dalam rangka pengembangan ilmu yang berhubungan dengan aspek kontribusi kepemimpinan kepala madrasah dan kinerja guru guna meningkatkan hasil belajar siswa.

\section{KEPUSTAKAAN ACUAN}
Abdul Halim Hanafi,2010 Metodologi Penelitian Kependidikan,STAIN Batusangkar Press, 2010


Jerry H. Makawimbang, 2012, Kepemimpinan Pendidikan Yang Bermutu, Bandung: Alfabeta.

Moh. Uzer Usman, 2002, Menjadi Guru Professional, Jakarta: Remaja Rosdakarya.

Nurkolis, 2003, Manajemen Berbasis Sekolah, Jakarta: PT.Gramedia Widiasarana Indonesia.
Purwanto, 2009, Evaluasi Hasil Belajar, Yogyakarta: PustakaBelajar.

Suharsimi Arikunto, 2005, Manajemen Penelitian, Jakarta: Renika Cipta.

Sugiyono, 2006, Metode Penelitian Administrasi, Bandung: Alfabeta. 